\title{
Double Skin Green Facade in Workplace for Enhancing Thermal Performance in Greater Cairo
}

\author{
Aya Mohamed Abdelhay Shaheen ${ }^{1}$ \\ Hanan Mostafa Kamal Sabry ${ }^{1}$ \\ Ahmed Atef El Dessoqy Faggal ${ }^{1}$ \\ ${ }^{1}$ Department of Architecture, Faculty of Engineering, Ain Shams University.
}

\begin{abstract}
Façade planting is an innovative idea to make use of plants in cooling the surrounding. Double Skin Green Façade is a type of green walls that offers psychological benefit in addition to its thermal performance. The aim of this research was to define the effect of Double Skin Green Façade on indoor thermal conditions. Orientation and cavity width were the parameters identified in this research in order to achieve maximum efficiency. A Double Skin Green Façade model was applied on an office building to investigate its thermal performance in Cairo, using Design Builder software. The simulation process was divided into three phases. The first phase aimed to define the day with extreme high temperature among the year to undergo further phases. The second phase intended to compare the performance of the green façade to that of the base case in south, east, and west orientations. Then the cavity width parameter was examined on third phase. Results showed improvement on indoor air temperature after applying Double Skin Green Façade. Moreover, the research recommended its application on the west orientation with 1.5 meters cavity width with respect to Cairo climatic conditions.
\end{abstract}

\section{Keywords}

Double Skin Green Façade (DSGF), Thermal performance, Orientation, Office building.

\section{Introduction}

Green wall is a general term that includes all vegetated vertical surfaces. It is a passive approach (Ling \& Chiang, 2018), which make use of plants regarding its benefits to human and environment. It has proved its benefits in urban, building and human scale.

For urban scale, Sheweka \& Magdy (2011) claimed that green walls helps reducing urban heat island effect; due to the increase of the vegetated surfaces instead of the built environment surfaces as masonry work. Masonry work is known to absorb and radiate more solar heat than the vegetated walls. Moreover, Cardoso \& Cohen (2009) recognized that green wall is considered as an air filtering device; as plants absorbs carbon oxides, volatile organic compounds, and heavy metal particles, reducing air pollution while increasing oxygen content 
through photosynthesis process. In addition, Ekren (2017) proved that green wall act as a noise barrier, reducing the transmission of sound levels.

For building scale, Sheweka \& Magdy (2011) examined thermal performance of green walls. They concluded that it acts as a barrier against wind, solar radiation, and so protects the building from excessive heat in summer and cold weather in winter. Accordingly, Baran \& Gültekin (2017) compared the energy consumption before and after adding green wall. They found that it allows less energy consumption for heating or cooling which leads to financial benefits.

For human scale, Lerner and Stopka (2016) observed that presence of plants in workplace provides workers with sense of satisfaction and motivation to do more, so productivity increases. Thus green walls provides human with positive experience defined by biophilia hypothesis; it has positive impact on human physical, mental and behavioral health.

This research focused on Double Skin Green Façade. It is a type of green wall in which the attachment of plants is through lightweight supporting structure, which enables the separation between the building façade and the vegetation surface (Susorova \& Bahrami, 2012). This separation enables the installation of green façade on windowed building envelope which creates positive experience for users; to have contact with nature as defined by 'biophilia' hypothesis. Consequently, Double Skin Green Façade has an advantage over the other types on applying green walls externally on building's skin.

Thermal performance of Double Skin Green Façade (DSGF) has been studied by several methods; field measurements, mathematical equations, simulation software. By using simulation software, many attempts were made to simulate properties of green walls either by developing mathematical models and integrating it with simulation software (Larsen, Filippin, \& Lesino, 2015) (Dahanayake \& Chow, 2017) or through defining the green wall composition by a set of layers, providing each layer with its properties (thickness, density, specific heat, conductivity, or thermal transmittance) as characterized in literature (Yoshimi \& Altan, 2011) (Vaezizadeh, Rashidisharifabad, \& Afhami, 2016). This research adopted the second approach as defined by Yoshimi \& Altan (2011).

Thermal performance of DSGF was affected by many parameters. However, it was observed that not all the parameters can be investigated through computer simulation; parameters related to plant species and its growth patterns must be investigated through field measurement (Maclvor \& Margolis, 2014). For Double Skin Green Façade, façade orientation, the cavity width, and window to wall ratio are parameters that can be investigated through computer simulation (Lin, Xiao, Musso, \& Lu, 2019). 
Accordingly, DSGF model was applied in this paper to be examined through simulation software. Façade orientation and cavity width were the parameters examined to show its effect.

\section{Objectives}

This paper contributes to improving thermal conditions in workplace, for the aim of increasing users' satisfaction and productivity in turn. The aim of this research was to define the role of the Double Skin Green Façade (DSGF) in enhancing thermal performance in the workplace. In addition, parameters (as orientation and cavity width) were examined to detect the most effective orientation for the green facade as well as the efficient cavity width.

\section{Methodology}

A Double Skin Green Façade model was applied on an office building to investigate its thermal performance using Design Builder software (version 6.1.0.006, 2000-2019 copyrights) for modelling and assigning activity template, construction template, and occupancy schedule. Moreover, Energy Plus (version 8.9.0) was used as an engine for thermal analysis and measurement of indoor thermal comfort. The weather file used in simulation was (EGY_Cairo.Intl.Airport.623660_ETMY.epw).

\subsection{Case Study Model Description}

The case study is an office building, consisting of six stories; ground floor and five typical floors. The ground floor comprises the entrance zone, office rooms for high managerial board, and services while the upper floors are typical universal spaces provided with service zone located in the building central core. This model represents the common features used in office buildings in Cairo.

The unit selected for thermal analysis is the office space of the third floor (the mid floor); as it represents the general case of intermediate floors. Floor area is around $2000 \mathrm{~m}^{2}$. Its height -from finish floor level to finish floor level- is $4 \mathrm{~m}$. The core zone was modelled as one zone for simplification which is thermally adiabatic. Figure 1 shows the architectural drawings of the studied unit.
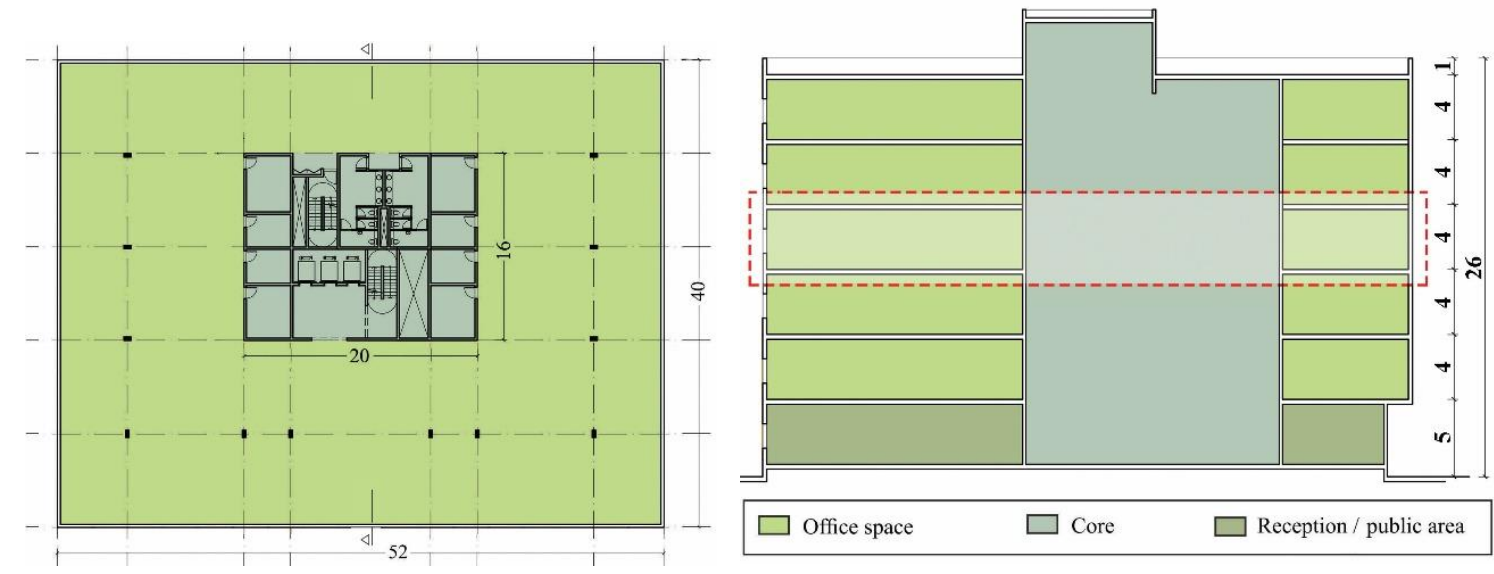

Figure 1: The Unit of Study 
The construction template provided in this study is based on the most common construction materials for walls and floors in Egypt. Table 1 demonstrates wall construction materials.

Table 1: Base Wall Construction Materials

\begin{tabular}{|l|l|l|}
\hline & Description & U value \\
\hline $\begin{array}{l}\text { Opaque } \\
\text { surfaces }\end{array}$ & $\begin{array}{l}\text { 20cm hollow cement brick and 2cm cement plaster from } \\
\text { both sides. }\end{array}$ & 2.443 \\
\hline $\begin{array}{l}\text { External } \\
\text { Glazing }\end{array}$ & 6mm. Single green panel & 5.778 \\
\hline $\begin{array}{l}\text { Internal } \\
\text { Glazing }\end{array}$ & $\begin{array}{l}\text { 6mm. Single clear panel } \\
\text { (in case of } D S G F \text { ) }\end{array}$ & 5.778 \\
\hline WWR & $\begin{array}{l}\text { For the investigated façade: } 50 \% \\
\text { For other 3 facades: } 30 \%\end{array}$ & \\
\hline
\end{tabular}

The Double Skin Green Façade was modelled using Design Builder according to Yoshimi \& Altan (2011); as the vegetation -external- skin was considered an opaque surface that consists of four layers; water vapour, leaves, air gap, and soft wood (stem). The cavity width was variable during the experiment to measure its effect. The generation of DSGF model was provided in Table 2 and Figure 2.

Table 2: The Construction of DSGF Using Design Builder

\begin{tabular}{|l|l|c|c|c|c|}
\hline \multicolumn{2}{|l|}{ Layers } & $\begin{array}{c}\text { Width } \\
(\mathrm{mm})\end{array}$ & $\begin{array}{c}\text { Density } \\
\left(\mathrm{Kg} / \mathrm{m}^{3}\right)\end{array}$ & $\begin{array}{c}\text { Specific heat } \\
(\mathrm{J} / \mathrm{kg} . \mathrm{K})\end{array}$ & $\begin{array}{c}\text { Conductivity } \\
(\mathrm{W} / \mathrm{mK})\end{array}$ \\
\hline 1 & Water vapour & 2 & 0.6 & 1966 & 5.56 \\
\hline 2 & Leaves & 1 & 533 & 100 & 0.4 \\
\hline 3 & Air gap & 125 & 1.3 & 1004 & 5.56 \\
\hline 4 & Soft wood (stem) & 15 & 110 & 1880 & 0.14 \\
\hline 5 & Cavity (air gap) & Variable & & & \\
\hline 6 & Cement Plaster & 20 & 950 & 840 & 0.35 \\
\hline 7 & $\begin{array}{l}\text { Hollow cement } \\
\text { brick }\end{array}$ & 200 & 1140 & 880 & 1.6 \\
\hline 8 & Cement plaster & 20 & 950 & 840 & 0.35 \\
\hline
\end{tabular}

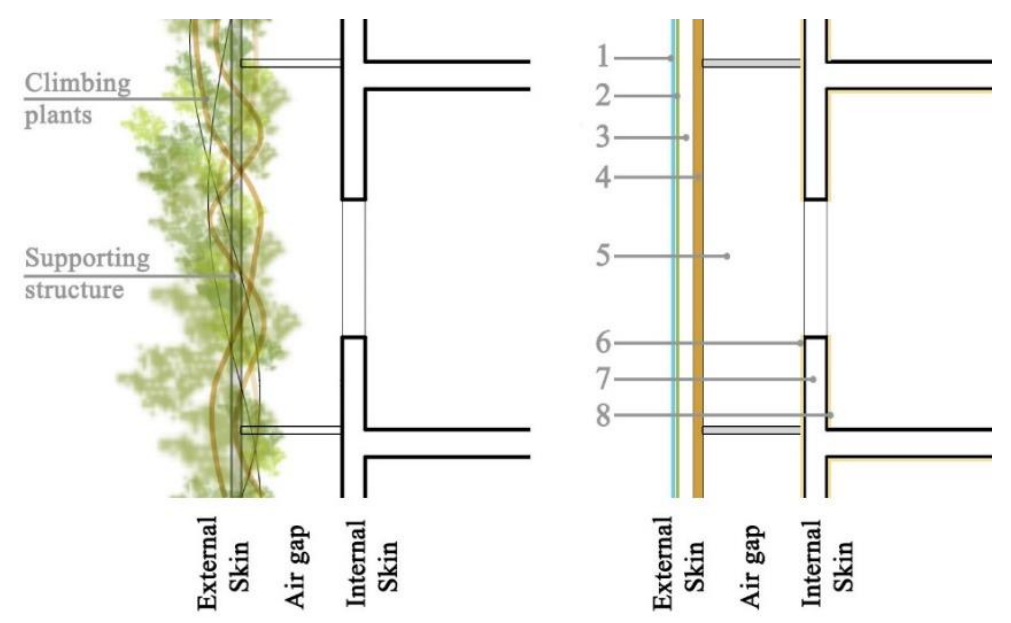

Figure 2: DSGF Model Generation 


\subsection{Simulation Phases}

The simulation process was divided into three consecutive phases.

\section{- $\quad$ First phase}

The first phase was considered as an introductory step in order to determine the day with the highest indoor air temperature among the year to undergo further measurements in the following phases.

In this phase, the studied unit of the base case model (Figure 3) underwent daily simulation using Energy Plus, then the operative temperature was compared in the summer design week to determine the day with the highest air temperature to undergo the following phases.

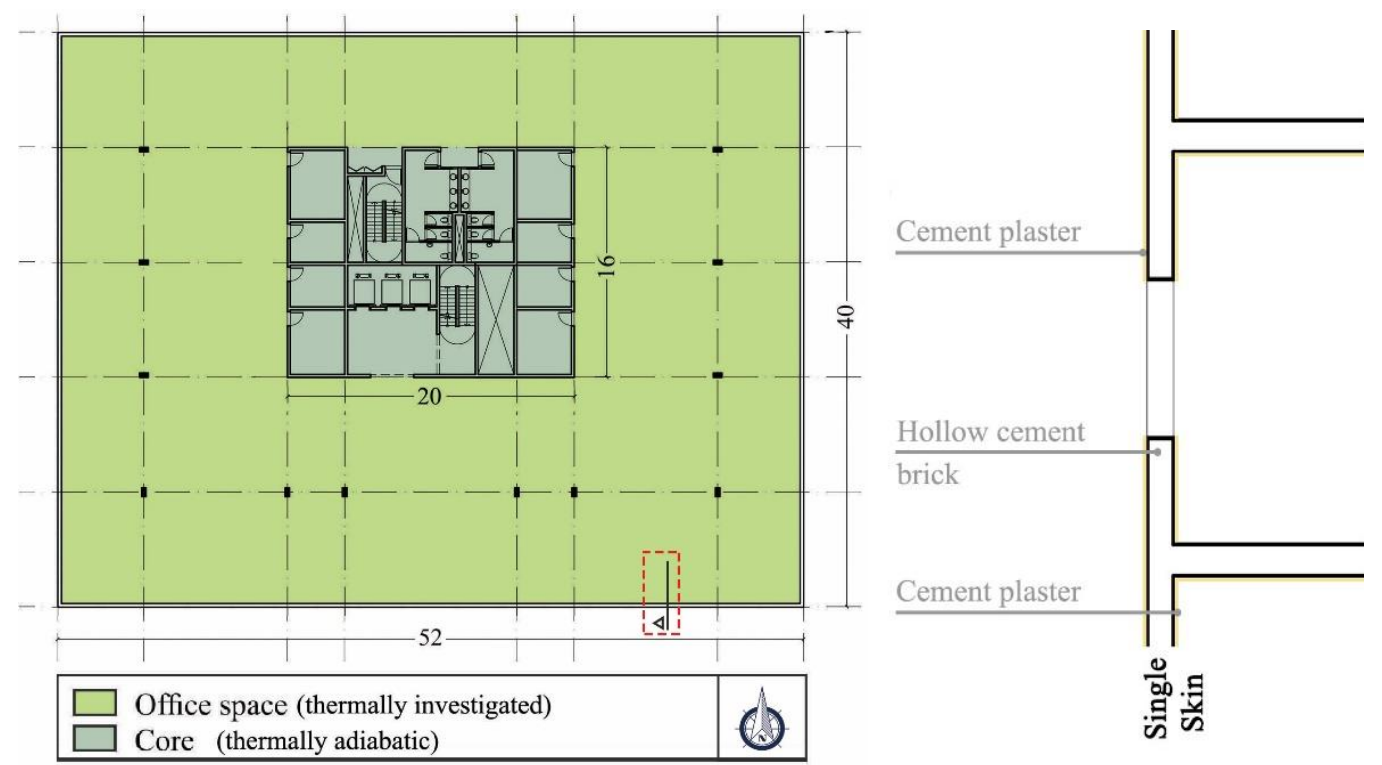

Figure 3: Base Case Model

\section{- $\quad$ Second phase}

The aim of this phase was to determine the effect of Double Skin Green Façade (DSGF) installation, by comparing the studied unit in the base case with the unit after adding the DSGF (Figure 4) in three orientations; south, west, and east. North orientation was neglected through measurements as no direct solar exposure faces the North orientation.

This phase underwent sub-hourly simulation using Energy Plus; the measurements were done during working hours (from $9 \mathrm{am}$ to $5 \mathrm{pm}$ ) for the day specified from the first phase to define the role of DSGF in achieving thermal comfort. The cavity width in this case was assumed to be 1.5 meters. 

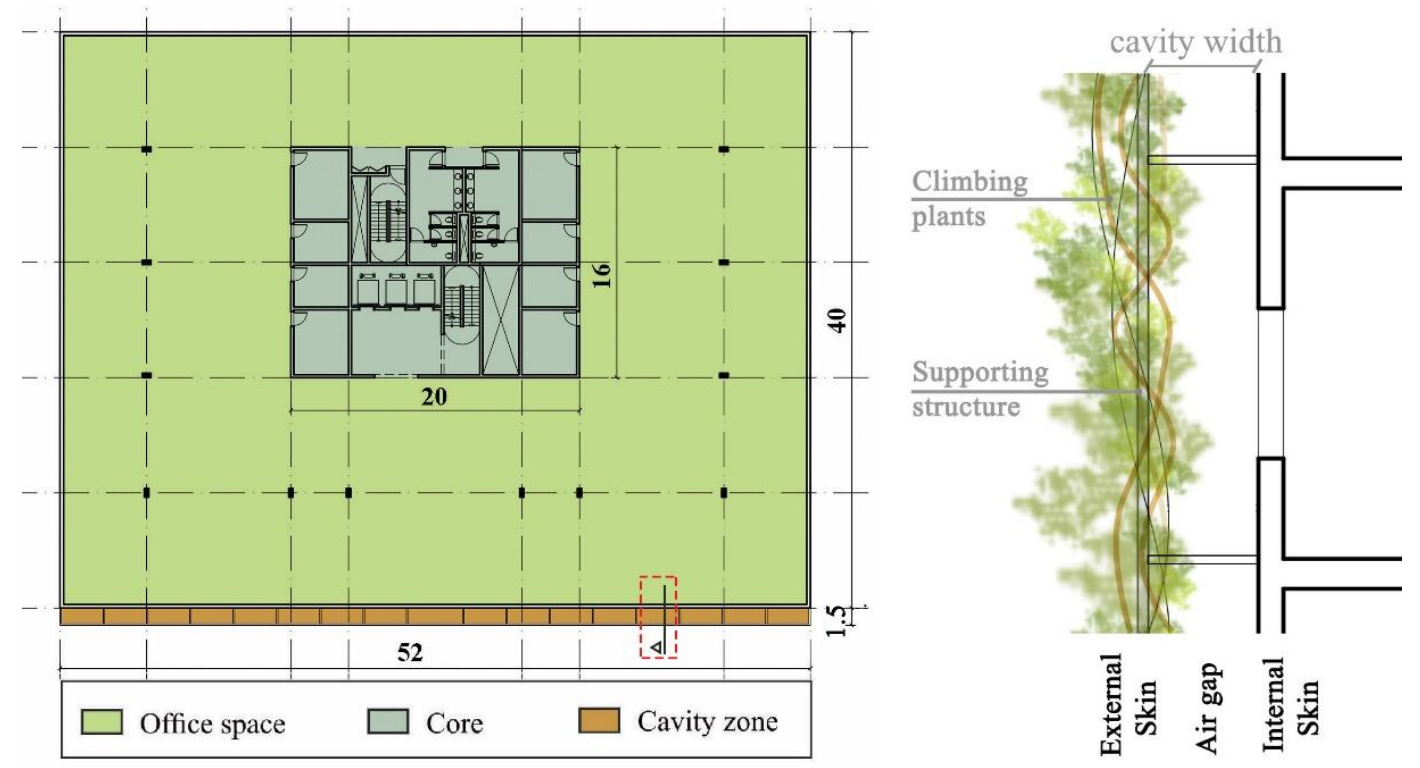

Figure 4: Model after Applying DSGF

\section{- $\quad$ Third phase}

The aim of this phase is to investigate the effect of changing cavity width on the indoor temperature for the studied unit. Thus the variable parameter in this phase is the cavity width while the orientation remained constant.

The experiment was set for the best orientation determined from phase two. It underwent sub-hourly simulation for the day specified from phase 1 as the extreme hot day. The operative temperature was compared during working hours (from $9 \mathrm{am}$ to $5 \mathrm{pm}$ ) for the four cases of variable cavity width;

- Case 1: $0.6 \mathrm{~m}$. (the minimum width for providing access for maintenance)

- Case 2:1 m.

- Case 3: $1.5 \mathrm{~m}$.

- Case 4: $2 \mathrm{~m}$.

\section{Results}

\section{- $\quad$ First Phase}

According to weather file of Cairo (EGY_Cairo.Intl.Airport.623660_ETMY.epw), the week ranges from $\left(19^{\text {th }}\right.$ to $\left.25^{\text {th }}\right)$ of August is the week with highest temperature among the year, which is defined in Energy Plus as summer design week. The operative temperature in the studied unit was compared for the specified week to find that $\mathbf{2 3}^{\text {rd }}$ of August is the day with the highest indoor air temperature among the whole year with an average temperature of $37^{\circ} \mathrm{C}$ (Figure 5), and so the following phases were performed on $23^{\text {rd }}$ of August. 


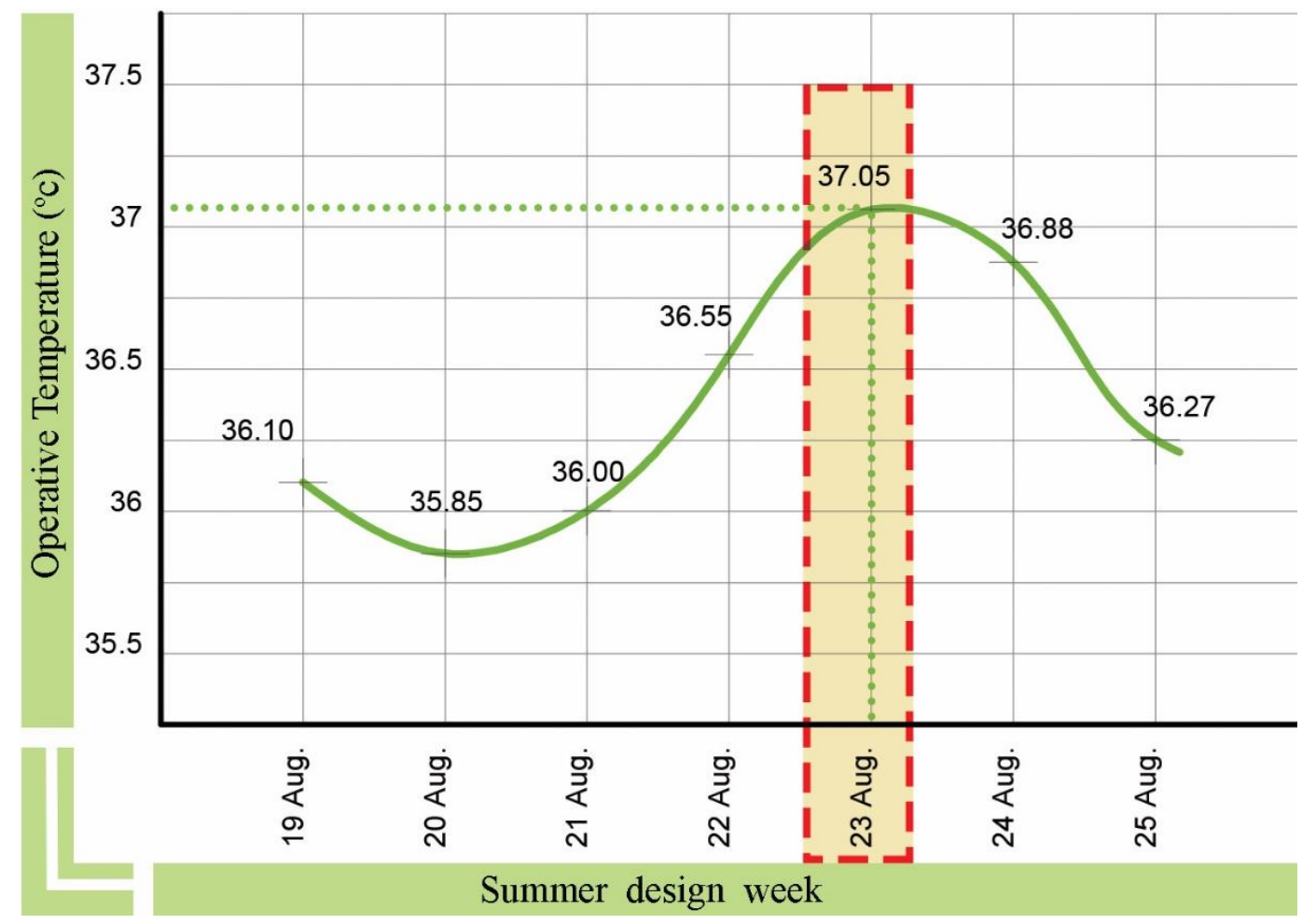

\section{Figure 5: Operative Temperature in Summer Design Week}

\section{- $\quad$ Second Phase}

In this phase, the operative temperature was measured in the studied unit of both cases; the base case (BC) and the case after adding Double Skin Green Façade (DSGF) in south, west, and east orientations. Table 3 mentioned the difference between operative temperature -measured in $\left({ }^{\circ} \mathrm{C}\right)$ - in base case and vegetated case during the working hours.

Table 3: Operative Temperature of Base Case and DSGF with Different Orientations

\begin{tabular}{|c|c|c|c|c|c|c|c|c|c|c|}
\hline \multicolumn{2}{|c|}{$\begin{array}{l}\text { Operative } \\
\text { temperature }\left({ }^{\circ} \mathrm{C}\right) \\
\text { /working hours }\end{array}$} & 9am & $10 \mathrm{am}$ & $11 \mathrm{am}$ & $12 \mathrm{pm}$ & $1 \mathrm{pm}$ & $2 \mathrm{pm}$ & $3 \mathrm{pm}$ & $4 \mathrm{pm}$ & $5 \mathrm{pm}$ \\
\hline \multirow{3}{*}{ 芳 } & $\mathrm{BC}$ & 37.24 & 37.54 & 37.8 & 38.24 & 38.73 & 39.15 & 39.4 & 39.58 & 39.89 \\
\hline & DSGF & 34.49 & 34.86 & 35.14 & 35.91 & 36.65 & 37.25 & 37.58 & 37.87 & 38.43 \\
\hline & Differen & 2.75 & 2.68 & 2.66 & 2.33 & 2.08 & 1.9 & 1.82 & 1.71 & 1.46 \\
\hline \multirow{3}{*}{$\frac{\overrightarrow{0}}{3}$} & $\mathrm{BC}$ & 37.61 & 37.89 & 38.11 & 38.5 & 39.04 & 39.56 & 39.9 & 40.15 & 40.54 \\
\hline & DSGF & 34.37 & 34.78 & 35.08 & 35.83 & 36.58 & 37.14 & 37.44 & 37.7 & 38.02 \\
\hline & Difference & 3.24 & 3.11 & 3.03 & 2.67 & 2.46 & 2.42 & 2.46 & 2.45 & 2.52 \\
\hline \multirow{3}{*}{ 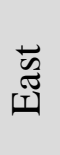 } & $\mathrm{BC}$ & 37.46 & 37.76 & 37.96 & 38.3 & 38.77 & 39.21 & 39.5 & 39.72 & 40.06 \\
\hline & DSGF & 34.67 & 35 & 35.28 & 36.06 & 36.85 & 37.52 & 37.86 & 38.15 & 38.8 \\
\hline & Difference & 2.79 & 2.76 & 2.68 & 2.24 & 1.92 & 1.69 & 1.64 & 1.57 & 1.26 \\
\hline
\end{tabular}

Enhancements occurred in operative temperature after adding DSGF in different cases of wall orientation was represented in Figure 6. 


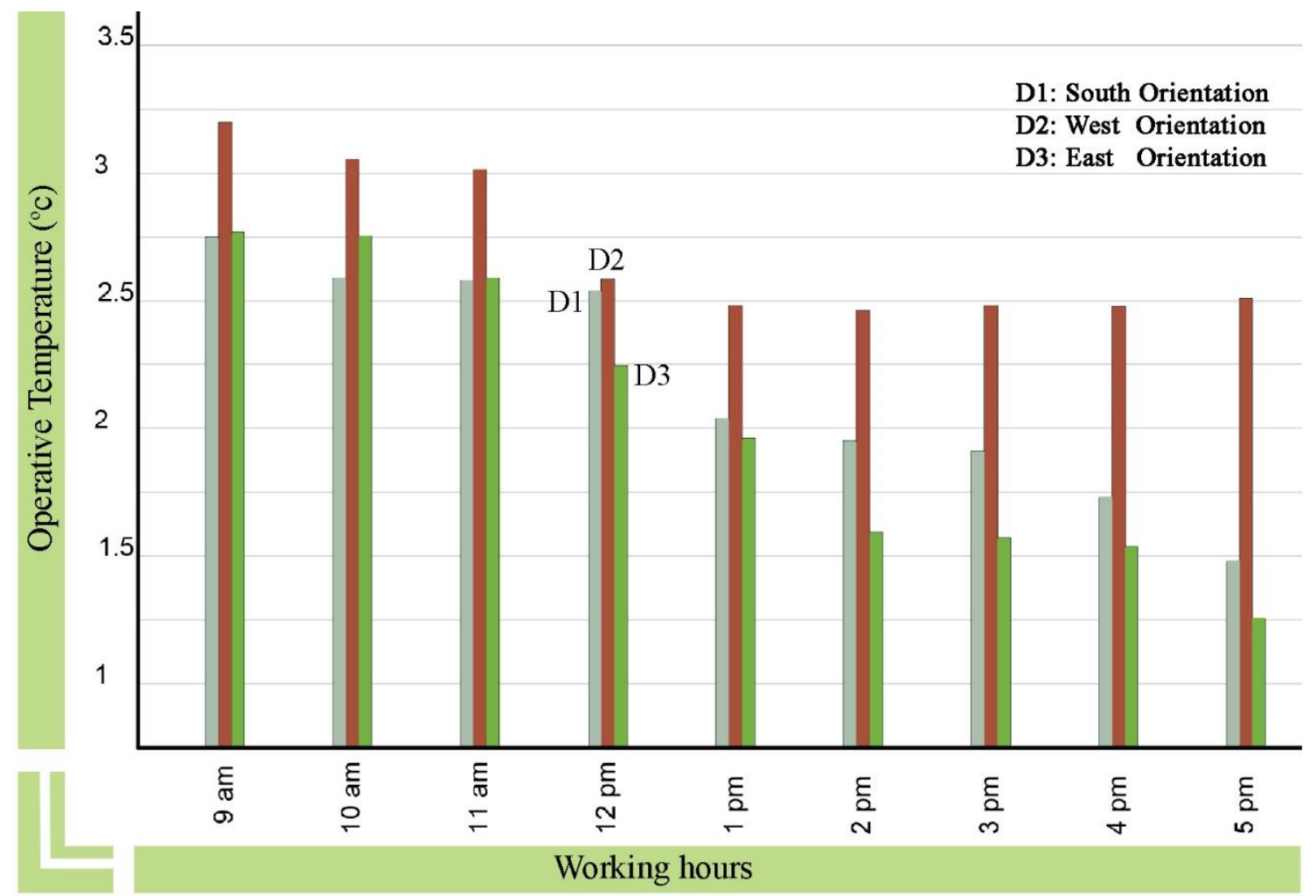

Figure 6: Enhancements Occurred for Different Orientations after Adding DSGF

Findings from Table 3 and Figure 6 were summarized in the following points;

- Green façade has improved thermal performance in working space by (1.26-3.24 ${ }^{\circ} \mathrm{C}$ ) depending on different orientations and at different times of the day.

- Generally, the maximum efficiency of DSGF occurred at morning (before $12 \mathrm{pm}$ ) regardless its orientation.

- The behavior of east and south DSGF reached its maximum efficiency at 9am and its effect was reduced till it reached its minimum value at 5pm, while the west DSGF reached its minimum value at $2 \mathrm{pm}$ then started to increase.

- On comparing between east and south DSGF, the eastern green facade thermal performance was little better than the southern by average $0.05^{\circ} \mathrm{C}$ at morning. Starting from $12 \mathrm{pm}$, the southern green facade thermal performance was better than the eastern. The difference was $0.09^{\circ} \mathrm{C}$ at 12 $\mathrm{pm}$ and increased till it reached $0.2^{\circ} \mathrm{C}$ at $5 \mathrm{pm}$.

- The western green facade had the best thermal performance during the examined hours. The difference reached to $1.26^{\circ} \mathrm{C}$ between east and west orientations at $5 \mathrm{pm}$.

\section{- Third Phase}

In this phase, the operative temperature was measured in the studied unit after adding DSGF on the examined wall which has west orientation. Cavity width was 
the variable to be examined in this phase. The measurements were done during the working hours as shown in Table 4.

Table 4: Operative Temperatures of DSGF with Different Cavity Widths

\begin{tabular}{|c|c|c|c|c|c|c|c|c|c|c|}
\hline $\begin{array}{l}\text { Operative } \\
\text { Temperature }\left({ }^{\circ} \mathrm{C}\right) \\
\text { /working hours }\end{array}$ & $9 \mathrm{am}$ & $10 \mathrm{am}$ & $11 \mathrm{am}$ & $12 \mathrm{pm}$ & $1 \mathrm{pm}$ & $2 \mathrm{pm}$ & $3 \mathrm{pm}$ & $4 \mathrm{pm}$ & $5 \mathrm{pm}$ \\
\hline \multicolumn{2}{|c|}{ Base Case } & 37.61 & 37.89 & 38.11 & 38.5 & 39.04 & 39.56 & 39.9 & 40.15 & 40.54 \\
\hline DSGF & $0.6 \mathrm{~m}$. & 34.42 & 34.84 & 35.13 & 35.88 & 36.62 & 37.19 & 37.49 & 37.76 & 38.1 \\
\hline \multicolumn{2}{|c|}{ Difference } & 3.19 & 3.05 & 2.98 & 2.62 & 2.42 & 2.37 & 2.41 & 2.39 & 2.44 \\
\hline DSGF & $1 \mathrm{~m}$. & 34.41 & 34.83 & 35.12 & 35.87 & 36.62 & 37.18 & 37.48 & 37.76 & 38.09 \\
\hline \multicolumn{2}{|c|}{ Difference } & 3.2 & 3.06 & 2.99 & 2.63 & 2.42 & 2.38 & 2.42 & 2.39 & 2.45 \\
\hline DSGF & $1.5 \mathrm{~m}$. & 34.37 & 34.78 & 35.08 & 35.83 & 36.58 & 37.14 & 37.44 & 37.7 & 38.02 \\
\hline \multicolumn{2}{|c|}{ Difference } & 3.24 & 3.11 & 3.03 & 2.67 & 2.46 & 2.42 & 2.46 & 2.45 & 2.52 \\
\hline DSGF 2 m. & 34.4 & 34.82 & 35.11 & 35.87 & 36.61 & 37.17 & 37.47 & 37.74 & 38.07 \\
\hline \multicolumn{2}{|c|}{ Difference } & 3.21 & 3.07 & 3 & 2.63 & 2.43 & 2.39 & 2.43 & 2.41 & 2.47 \\
\hline
\end{tabular}

Enhancements occurred in operative temperature after adding DSGF in different cases of cavity width was represented in Figure 7.

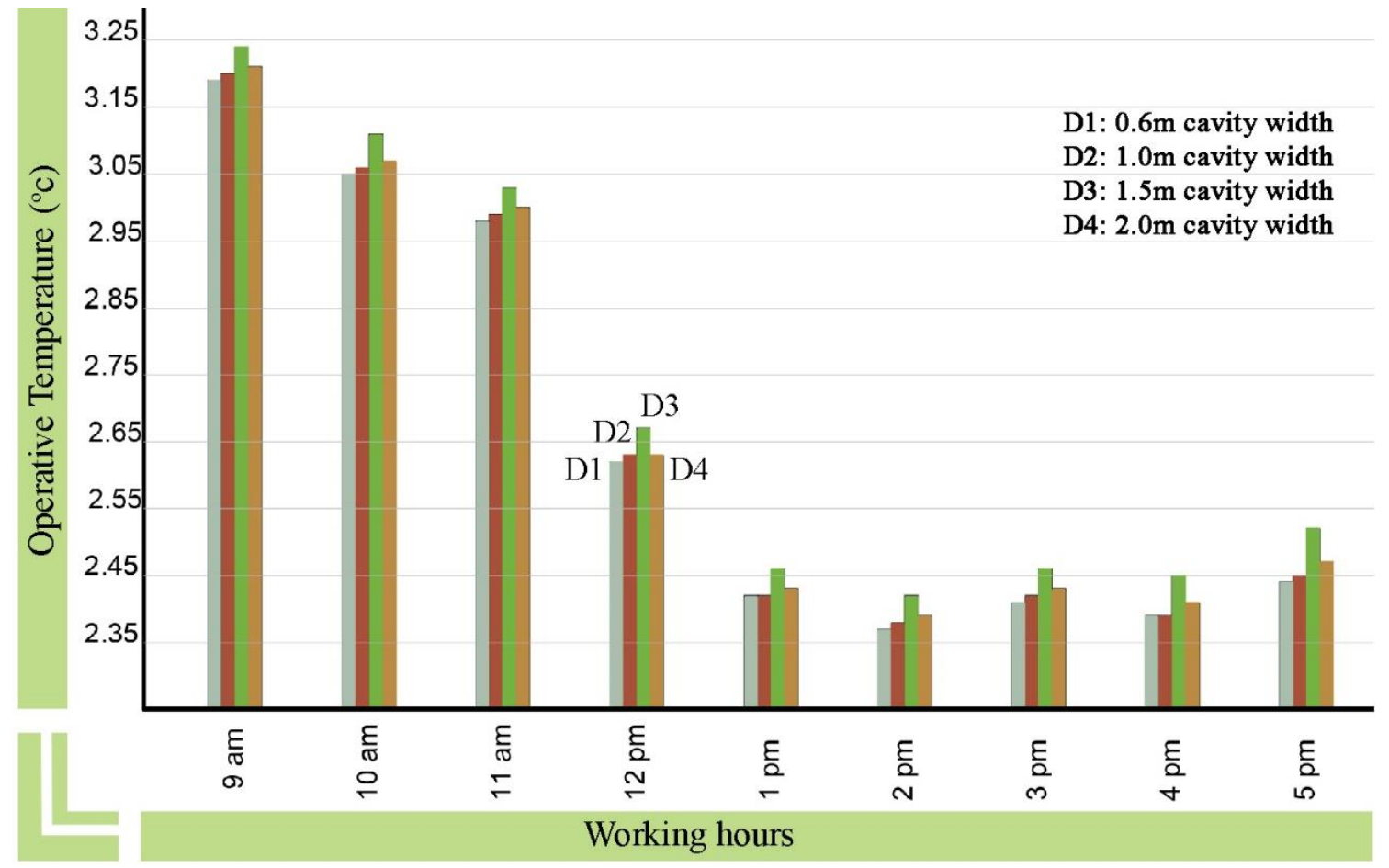

Figure 7: Enhancements Occurred by Adding DSGF with Different Cavity Widths

Findings from Table 4 and Figure 7 were summarized in the following points;

- Generally, the 4 cases (of different cavity width) had the same attitude, but with different values. Their maximum efficiency was at 9 am, then reduced till reached their minimum performance at $2 \mathrm{pm}$, and then increased again. 
- The impact of this parameter (cavity width variation) was not significant. The $0.6 \mathrm{~m}$ cavity width had the least performance, while the $1.5 \mathrm{~m}$ cavity width had the best performance. However, the variation in temperature between the two -previously mentioned- cases was about $\left(0.05-0.07^{\circ} \mathrm{C}\right)$.

- As observed, the performance of DSGF whose cavity widths were $(0.6 \mathrm{~m}$, $1 \mathrm{~m}$, and $2 \mathrm{~m}$ ) provided near values for thermal enhancement, the temperature difference was about $\left(0.01-0.02^{\circ} \mathrm{C}\right)$.

- As a conclusion, cavity width of 1.5 meters had the best performance among others for Cairo climatic conditions. Thermal performance was less efficient by increasing or decreasing the cavity width than 1.5 meters. However, the effect of this parameter was insignificant; as the temperature variation was less than $0.1^{\circ} \mathrm{C}$.

\section{Discussion and Conclusion}

The findings of this study showed that Double Skin Green Façade had the best performance when it was west directed with 1.5 meters cavity width. Enhancements in indoor operative temperature has reached (2.5-3.2) ${ }^{\circ} \mathrm{C}$ during the examined working hours. These results concerning the hot arid climate of Egypt (especially Cairo) that may differ in other climatic conditions.

For future investigations considering Double Skin Green Façade installment, it is recommended to study the effect of window to wall ratio parameter. In addition, its application in different locations with different climatic conditions might affect the results leading to different outcomes.

\section{References}

Baran, Y., \& Gültekin, A. B. (2017, March). Green Wall Systems: A Literature Review. International Sustainable Buildings Symposium, pp. 82-96.

Cardoso, N., Cohen, A. (2009). Do Work Environments Have an Effect on Productivity and Creativity?

Dahanayake, K. K., \& Chow, C. L. (2017). Studying the Potential of Energy Saving through Vertical Greenery Systems: Using EnergyPlus Simulation Program. Energy and Buildings, 138, 47-59.

Ekren, E. (2017). Advantages and Risks of Vertical Gardens. Journal of Bartin Faculty of Forestry, 51-57.

Kontoleon, K. J., \& Eumorfopoulou, E. A. (2010). The Effect of the Orientation and Proportion of a Plant-Covered Wall Layer on the Thermal Performance of a Building Zone. Building and Environment, 45, 1287-1303.

Larsen, S. F., Filippin, C., \& Lesino, G. (2015). Modeling Double Skin Green Facades with Traditional Thermal Simulation Software. Solar Energy, 121, 56-67. 
Lee, L. S., \& Jim, C. Y. (2017). Subtropical Summer Thermal Effects of Wirerope Climber Green Walls with Different Air-Gap Depths. Building and Environment, 126, 1-12.

Lee, L. S., \& Jim, C. Y. (2019). Transforming Thermal-Radiative Study of a Climber Green Wall to Innovative Engineering Design to Enhance Building-Energy Efficiency. Journal of Cleaner Production, 224, 892-904.

Lerner, A., Stopka, M. (2016). The Financial Benefits of Biophilic Design in the Workplace: A Review and Summary of Current Research. Chicago: MIST Environment.

Lin, H., Xiao, Y., Musso, F., \& Lu, Y. (2019). Green Façade Effects on Thermal Environment in Transitional Space: Field Measurement Studies and Computational Fluid Dynamics Simulations. Sustainability, 11(20), pp. 56915712.

Ling, T.-Y., \& Chiang, Y.-C. (2018). Well-being, Health and Urban CoherenceAdvancing Vertical Greening Approach Toward Resilience: A Design Practice Consideration. Journal of Cleaner Production, 182, 187-197.

Maclvor, J. S., \& Margolis, L. (2014). Cooling of a South-Facing Wall Using a DoubleSkin Green Façade in a Temperate Climate. The 2014 Annual Meeting of the International Plant Propagators Society, 1085, pp. 185-194.

Prihatmanti, R., \& Taib, N. (2017). Improving Thermal Comfort through Vertical Greeneries in Transitional Spaces for the Tropical Climate: A Review. Engineering Technology, 4(3), 116-123. doi:10.5176/2251-3701_4.3.212

Sheweka, S., \& Magdy, N. (2011). The Living walls as an Approach for a Healthy Urban Environment. Energy Procedia 6 (pp. 592-599). Cairo: Elsevier Ltd. doi:10.1016/j.egypro.2011.05.068

Sulaiman, M. K., Shahidan, M. F., Jamil, M., \& Zain, M. F. (2018). Percentage Coverage of Tropical Climbing Plants of Green Facade. IOP Conference Series: Materials Science and Engineering. 401. IOP Publishing.

Susorova, I., \& Bahrami, P. (2012). Facade-Integrated Vegetation as an Environmental Sustainable Solution for Energy-Efficient Buildings. MADE Research Journal of Cardiff University, 7-14.

Vaezizadeh, F., Rashidisharifabad, S., \& Afhami, R. (2016). Investigating the Cooling Effect of Living Walls in the Sunken Courtyards of Traditional Houses in Yazd. European Journal of Sustainable Development, 5(2), 27-40.

Widiastuti, R., Caesarendra, W., Prianto, E., \& Budi, W. S. (2018). Study on the Leaves Densities as Parameter for Effectiveness of Energy Transfer on the Green Facade. Buildings, 8(10), pp. 138-152. 
Yoshimi, J., \& Altan, H. (2011). Thermal Simulations on the Effects of Vegetated Walls on Indoor Building Environments. Proceedings of Building Simulation, (pp. 14381443). 